Jurnal Ilmu dan Teknologi Kesehatan

Vol 8, No 1, September 2020,

ISSN: 2338-9095 (Print)

ISSN: 2338-9109 (online)

\title{
Digital Parenting The Android-Based Monitoring of Children's Growth and Development for Working Mothers
}

\author{
Imas Mulyani, La Ode Abdul Rahman, Nur Agustini \\ Universitas Indonesia, Indonesia \\ E-mail: imas.mulyani.im82@gmail.com
}

\begin{abstract}
Article history
Posted, May 3rd, 2020

Reviewed, July 10th, 2020

Received, Sept 27th, 2020
\end{abstract}

\begin{abstract}
The growth and development of children are closely related to the role of a mother, not a few mothers, and having the task of caring for children and working women, which will lead to suboptimal childcare. At this time, many android-based information system facilities that can be used to streamline child care for a mother who is a working woman. This study aimed to provide an overview and ideas of using android-based digital media in childcare to maximize children's growth and development for working mothers with a literature review method. From the study results and review of 10 selected journals, it was concluded that for parents of workers who cannot maximize childcare time or parenting time, many applications could facilitate parents to monitor the child's growth and development safely. The development of a child health nursing management information system can include healthy children, sick children, education, environment, and parenting patterns. The implication of developing a child health nursing management information system during parenting is very useful ad preventive and promotive action in children's health. Child nurses can effectively, efficiently, quickly, and accurately identify problems that arise in the preventive process so that they are expected to make nursing interventions that are also right on target.
\end{abstract}

Keywords: android application; child growth and development; pediatric nursing; working mothers

\begin{abstract}
ABSTRAK
Pertumbuhan dan perkembangan anak sangat erat kaitannya dengan peran seorang ibu, tidak sedikit seorang ibu selain mempunyai tugas dalam pengasuhan anak juga sebagai wanita pekerja, dimana dalam hal tersebut akan mengakibatkan tidak maksimalnya dalam pengasuhan anak. Pada masa saat ini banyak fasilitas sistem informasi berbasis android yang dapat dimanfaatkan untuk mengefektifkan pengasuhan anak bagi seorang ibu yang menjadi wanita yang bekerja. Tujuan dari penelitian ini untuk memberikan gambaran dan gagasan penggunaan media digital berbasis android dalam pengasuhan anak untuk memaksimalkan pertumbuhan dan perkembangan anak


bagi ibu pekerja dengan metode tinjauan literatur. Dari hasil telaah dan review 10 jurnal pilihan, didapatkan suatu kesimpulan bahwa bagi orang tua pekerja yang tidak dapat memaksimalkan waktu pengasuhan anak banyak aplikasi yang dapat memfasilitasi orang tua untuk melakukan monitoring pertumbuhan dan perkembangan anak secara aman. Pengembangan sistem informasi manajemen keperawatan kesehatan anak dapat meliputi kondisi anak sehat, anak sakit, pendidikan, lingkungan dan pola pengasuhannya. Implikasi dari pengembangan sistem informasi manajemen keperawatan kesehatan anak pada masa pengasuhan sangat bermanfaat sebagai tindakan preventif dan promotive dalam kesehatan anak. Perawat anak dapat dengan efektif, efisien, cepat dan tepat mengetahui masalah yang timbul dalam proses preventif sehingga diharapkan dapat membuat intervensi keperawatan yang juga tepat sasaran.

Kata Kunci : aplikasi android; pertumbuhan dan perkembangan anak; keperawatan anak; ibu pekerja

\section{INTRODUCTION}

Growth and development are interconnected and continuous processes in infancy and childhood. Growth refers to an increase in physical size. Development is a sequential process, during which babies and children acquire various skills and functions (Terri \& Carman, 2012). In the UUK (Unit Koordinasi Kerja) Growth and development of social pediatrics, it is stated that the stages of child development are divided into the perinatal period, infancy, toddlerhood, preschool/early childhood, and school period (Soetjiningsih \& IG. N. Gde Ranuh, 2016). Where at these times, really need a maximum upbringing. However, for working mothers, of course, this can be an obstacle to the child's strength. With the development of technology science, of course, this will greatly help overcome childcare for working mothers. People can already choose various android-based applications for every need.

In KBBI (2008), android means a robot that is similar to a human, on that this basis of which android-based digital parenting developed. The role and function of the family are very important in the child's nursing process. Children need access to care that is continuous, comprehensive, coordinated, family-centered, and sympathetic. This upbringing needs to focus on changing their physical development and emotional needs. Pediatric nurses provide this care by focusing on the family, providing atraumatic therapeutic care, and using evidence-based practice. Parents or guardians have an important role in the health and well-being of children. (Terri \& Carman, 2012). The development of 
information technology must be related to the first five years of children's life (toddlers), which is a period that is very sensitive to the environment. This period lasts very short and cannot be repeated, so the toddler period is called the "golden period", "window of opportunity", and "critical period". Comprehensive and quality development of children through simulation activities, early detection, and intervention of toddlers growth and development deviations are carried out at this "critical period".

Currently, the use of information systems in the medical world is very much. However, some have not used information systems to help the work of a medical worker, especially in helping the development of toddlers (Sudarmilah \& Pratisti, 2014). Android application programs related to childcare include having applications that can access normal growth and development targets, identification of nutritional status, games for children, and audio-visual remote communication service applications. A study explained that the experience of using digital media was obtained from an early age because the tools for accessing social media were already available at home. Families had televisions, computers, laptops, smartphones, and tablets. Based on
(Hardersen \& Guðmundsdóttir, 2012), a study on the use of technology among preschool children in Norway, 58\% of children aged 0-6 years use online digital media. According to Findahl (2013), 70\% of Swedish children age 3-4 years use digital media. Furthermore, in ten countries, digital surveys reveal this, and $81 \%$ of mothers have digitally uploaded a photo of their children aged 0-2 years (Altun, 2019).

Mobile information and communication technology (ICT) can improve staff performance in their ability to carry out health promotion, collect and report timely information on family health, provide health services such as vaccines and refer families to appropriate local health services. When mobile ICT tools are used by staff, the device can increase caregiver confidence in messages sent and increase staff confidence in their work (Westgard et al., 2019). This literature review study was conducted to describe the analysis of the application of information systems on android-based parenting, which can include monitoring growth and development and the good or bad consequences of its use. In this study, the researcher will conclude from various literature sources regarding digital parenting that is the actual mode and has

\section{DOI 10.32668/jitek.v8i1.352}


gone through the data collection stage through a literature review.

\section{METHOD}

The method used in this research is a literature review, a study conducted to analyze the literature selected from various sources to form a new idea conclusion. The journals used in this study are journals that discuss topics with keywords 1) Android Application, 2) Child Growth and Development, 3) Pediatric Nursing, 4) Parenting patterns for working mothers. Through the online database, searches for academic journals include EBSCO, Ebrary, ProQuest, and PubMed from 2011-2019.

\section{RESULTS AND DISCUSSION}

The following are selected journals that researchers analyzed in this literature review study :

Table 1. Details of the main choice journal results for literature review

\begin{tabular}{|c|c|c|c|c|c|c|}
\hline No & $\begin{array}{l}\text { Author/ } \\
\text { Year }\end{array}$ & $\begin{array}{l}\text { Title } \\
\text { Research }\end{array}$ & Journal & $\begin{array}{c}\text { Aim } \\
\text { Research }\end{array}$ & $\begin{array}{l}\text { Method } \\
\text { Research }\end{array}$ & Result Research \\
\hline 1 & (Altun, 2019) & $\begin{array}{l}\text { An } \\
\text { investigation } \\
\text { of preschool } \\
\text { children's } \\
\text { digital } \\
\text { footprints } \\
\text { and screen } \\
\text { times, And } \\
\text { parents' } \\
\text { sharing and } \\
\text { digital } \\
\text { parenting } \\
\text { roles }\end{array}$ & $\begin{array}{l}\text { Internati } \\
\text { onal } \\
\text { Journal } \\
\text { of } \\
\text { Eurasia } \\
\text { Social } \\
\text { Sciences }\end{array}$ & $\begin{array}{l}\text { To investigate } \\
\text { the activities of } \\
\text { preschool } \\
\text { children in } \\
\text { digital } \\
\text { environments, } \\
\text { their screen } \\
\text { time and digital } \\
\text { footprints, and } \\
\text { digital } \\
\text { parenting roles } \\
\text { within their } \\
\text { families. }\end{array}$ & $\begin{array}{l}\text { cross- } \\
\text { sectional } \\
\text { study }\end{array}$ & $\begin{array}{l}\text { The data obtained by families have } \\
\text { televisions, computers, laptops, } \\
\text { smartphones, and tablets. Children in } \\
\text { digital access through computers, tablets, } \\
\text { and smartphones. Moreover, parents are } \\
\text { also involved in sharing information about } \\
\text { children on social media even though it is } \\
\text { dangerous for the privacy of the child's } \\
\text { identity. Moreover, there are parental } \\
\text { concerns about digital media, which can } \\
\text { cause emotional development disorders } \\
\text { and dependence because they spend much } \\
\text { time using digital media. Furthermore, } \\
\text { some parents support the use of digital } \\
\text { media. }\end{array}$ \\
\hline 2 & $\begin{array}{l}\text { Madianou } \\
\text { \& Miller, } \\
\text { 2011) }\end{array}$ & $\begin{array}{l}\text { Mobile } \\
\text { phone } \\
\text { parenting: } \\
\text { Reconfiguri } \\
\text { ng } \\
\text { relationship } \\
\text { S between } \\
\text { Filipina } \\
\text { migrant } \\
\text { mothers } \\
\text { and their } \\
\text { left-behind } \\
\text { children }\end{array}$ & $\begin{array}{l}\text { New } \\
\text { media \& } \\
\text { society }\end{array}$ & $\begin{array}{l}\text { Draws on } \\
\text { comparative } \\
\text { research with } \\
\text { UK-based } \\
\text { Filipina } \\
\text { migrants - } \\
\text { mainly } \\
\text { domestic } \\
\text { workers and } \\
\text { nurses - and } \\
\text { their left- } \\
\text { behind }\end{array}$ & $\begin{array}{l}\text { Directly } \\
\text { compare the } \\
\text { experience }\end{array}$ & $\begin{array}{l}\text { For young children, a video connection can } \\
\text { have much of the same effect as a physical } \\
\text { presence. This is a significant finding } \\
\text { because it is the first empirical } \\
\text { demonstration and shows considerable } \\
\text { promise in video communication as a } \\
\text { means of maintaining family relationships } \\
\text { when physical presence is not } \\
\text { possible. Mobile phone communication } \\
\text { has significantly improved their ability to } \\
\text { parent at a distance. }\end{array}$ \\
\hline
\end{tabular}




\begin{tabular}{|c|c|c|c|c|c|c|}
\hline & & & & $\begin{array}{l}\text { children in the } \\
\text { Philippines }\end{array}$ & & \\
\hline 3 & $\begin{array}{l}\text { (van Heerden } \\
\text { et al., 2017) }\end{array}$ & $\begin{array}{l}\text { App- } \\
\text { Supported } \\
\text { Promotion } \\
\text { of Child } \\
\text { Growth } \\
\text { and } \\
\text { Developme } \\
\text { nt by } \\
\text { Community } \\
\text { Health } \\
\text { Workers in } \\
\text { Kenya: } \\
\text { Feasibility } \\
\text { and } \\
\text { Acceptab } \\
\text { ility } \\
\text { Study }\end{array}$ & $\begin{array}{l}\text { JMIR } \\
\text { Mhealth } \\
\text { Uhealth }\end{array}$ & $\begin{array}{l}\text { To test the } \\
\text { Information for } \\
\text { Action (IFA) } \\
\text { mobile phone } \\
\text { app's feasibility } \\
\text { and } \\
\text { acceptability, } \\
\text { provide } \\
\text { accountability, } \\
\text { learning, and } \\
\text { correction, } \\
\text { leading to } \\
\text { improvement. }\end{array}$ & $\begin{array}{l}\text { Qualitative } \\
\text { assessment }\end{array}$ & $\begin{array}{l}\text { The application was accounted for to } \\
\text { encourage intuitive discourse among } \\
\text { CHVs and guardians, prompting improved } \\
\text { nature of home visits. Parental figures } \\
\text { portrayed the application as moving the } \\
\text { relationship from feeling annoyed by } \\
\text { CHVs to encountering veritable } \\
\text { enthusiasm from CHVs. CHVs detailed } \\
\text { practicality challenges fundamentally } \\
\text { identified with foundation. The restricted } \\
\text { battery life of cell phones joined with the } \\
\text { absence of promptly accessible power } \\
\text { made it hard to keep the telephones } \\
\text { charged. CHVs revealed beginning } \\
\text { nervousness as first-time cell phone } \\
\text { clients, including worries about utilizing } \\
\text { the IFA application. With time, expanded } \\
\text { degrees of certainty were seen. }\end{array}$ \\
\hline 4 & $\begin{array}{l}\text { (Papadakis \& } \\
\text { Kalogiannakis, } \\
\text { 2017) }\end{array}$ & $\begin{array}{l}\text { Mobile } \\
\text { educational } \\
\text { applications } \\
\text { for } \\
\text { children. } \\
\text { What } \\
\text { educators } \\
\text { and parents } \\
\text { need to } \\
\text { know. }\end{array}$ & $\begin{array}{l}\text { Internatio } \\
\text { nal } \\
\text { Journal } \\
\text { of } \\
\text { Mobile } \\
\text { Learning } \\
\text { and } \\
\text { Organisat } \\
\text { ion }\end{array}$ & $\begin{array}{l}\text { The writing } \\
\text { audit presents } \\
\text { the most } \\
\text { recent } \\
\text { discoveries } \\
\text { identified } \\
\text { with the } \\
\text { genuine } \\
\text { instructive } \\
\text { estimation of } \\
\text { these 'self- } \\
\text { broadcasted' } \\
\text { instructive } \\
\text { applications. }\end{array}$ & $\begin{array}{l}\text { Literature } \\
\text { Review }\end{array}$ & $\begin{array}{l}\text { From the examination, it is inferred that } \\
\text { there are many uses for choosing the most } \\
\text { fitting instructive devices for kids, which } \\
\text { will encourage the instructive cycle for } \\
\text { instructors and teachers. }\end{array}$ \\
\hline & $\begin{array}{l}\text { (Westgard et } \\
\text { al., 2019) }\end{array}$ & $\begin{array}{l}\text { mHealth } \\
\text { tool to } \\
\text { improve } \\
\text { community } \\
\text { health } \\
\text { agent } \\
\text { performanc } \\
\text { e for a child } \\
\text { developmen } \\
t: \text { study }\end{array}$ & BMJ Open & $\begin{array}{l}\text { The } \\
\text { examination's } \\
\text { target is to } \\
\text { assess the } \\
\text { effect of the } \\
\text { mHealth } \\
\text { apparatus } \\
\text { (tablet with } \\
\text { application) on } \\
\text { youngster } \\
\text { create ment }\end{array}$ & $\begin{array}{l}\text { The study } \\
\text { hypothesizes } \\
\text { - an } \\
\text { experimenta } \\
\text { l cluster } \\
\text { randomized } \\
\text { controlled } \\
\text { trial, The } \\
\text { current } \\
\text { investigation }\end{array}$ & $\begin{array}{l}\text { Exploration has demonstrated that } \\
\text { versatile data and correspondence } \\
\text { innovation (ICT) can improve staff } \\
\text { execution in their capacity to complete } \\
\text { well-being advancement, gather and report } \\
\text { opportune data on family well-being, give } \\
\text { well-being administrations, for example, } \\
\text { antibodies, and allude families to fitting } \\
\text { nearby well-being administrations. What } \\
\text { is more, when staff members utilize } \\
\text { versatile ICT instruments, the gadget can }\end{array}$ \\
\hline
\end{tabular}




\begin{tabular}{|c|c|c|c|c|c|c|}
\hline & & $\begin{array}{l}\text { protocol for } \\
\text { a } \\
\text { cluster- } \\
\text { randomized } \\
\text { a controlled } \\
\text { trial in } \\
\text { Peru }\end{array}$ & & $\begin{array}{l}\text { and sustenance } \\
\text { status of kids } \\
\text { matured } 6 \text { to } \\
\text { three years } \\
\text { contrasted and } \\
\text { kids who get } \\
\text { home visits } \\
\text { from CHA } \\
\text { without the } \\
\text { mHealth } \\
\text { instrument. }\end{array}$ & & $\begin{array}{l}\text { build a guardian trust in the messages sent } \\
\text { and increment staff trust in their work. } \\
\text { Through the usage of science } \\
\text { development, developments in ICT, and } \\
\text { methodologies for youngster well-being } \\
\text { and improvement can be reached out to } \\
\text { low-asset settings to enable assets and } \\
\text { spread the advantages of innovative } \\
\text { advances. }\end{array}$ \\
\hline & $\begin{array}{l}\text { Wang et al., } \\
2018)\end{array}$ & $\begin{array}{l}\text { The } \\
\text { Research } \\
\text { and } \\
\text { Developme } \\
\text { nt of } \\
\text { Growth } \\
\text { Curve for } \\
\text { Children's } \\
\text { Height and } \\
\text { Weight on } \\
\text { Android } \\
\text { Platform }\end{array}$ & $\begin{array}{l}\text { Internation } \\
\text { al } \\
\text { Congress } \\
\text { on Image } \\
\text { and Signal } \\
\text { Processing } \\
\text { BioMedica } \\
1 \\
\text { Engineerin } \\
\text { g and } \\
\text { Informatic } \\
\mathrm{s}\end{array}$ & $\begin{array}{l}\text { Portray and } \\
\text { present } \\
\text { framework } \\
\text { engineering } \\
\text { plan and } \\
\text { development, } \\
\text { innovation } \\
\text { determination, } \\
\text { information } \\
\text { base plan and } \\
\text { usage, and } \\
\text { acknowledgme } \\
\text { nt of Android's } \\
\text { essential } \\
\text { capacities in } \\
\text { assessing kids' } \\
\text { development } \\
\text { and } \\
\text { improvement. }\end{array}$ & $\begin{array}{l}\text { Recording } \\
\text { and } \\
\text { evaluation }\end{array}$ & $\begin{array}{l}\text { Through the Android program, records and } \\
\text { assessments of kids' development and } \\
\text { improvement are acquired, physical } \\
\text { advancement is assessed depending on the } \\
\text { youngster's sex, date of birth, weight, and } \\
\text { stature information. Development and } \\
\text { advancement bend can be attracted } \\
\text { consequently as per the past development } \\
\text { and improvement records of youngsters, } \\
\text { and dynamic following of kids' } \\
\text { improvement the board to be } \\
\text { accomplished. }\end{array}$ \\
\hline 7 & $\begin{array}{l}\text { (Kucirkova et } \\
\text { al., 2013) }\end{array}$ & $\begin{array}{l}\text { Sharing } \\
\text { personalize } \\
\text { d stories on } \\
\text { iPads: a } \\
\text { close look } \\
\text { at one } \\
\text { parent-child } \\
\text { interaction }\end{array}$ & $\begin{array}{l}\text { Literacy } \\
\text { UKLA }\end{array}$ & \begin{tabular}{l|} 
To get some \\
answers \\
concerning \\
how explicit \\
iPad \\
applications \\
influence \\
parent- \\
youngster \\
story-sharing \\
collaborations.
\end{tabular} & $\begin{array}{l}\text { Case-study } \\
\text { approach }\end{array}$ & $\begin{array}{l}\text { This examination found the setting of } \\
\text { sharing stories intervened by applications } \\
\text { to deliver an amicable and smooth } \\
\text { communication, accomplishing } \\
\text { intelligibility commonplace of 'upbeat' } \\
\text { oral stories. This shows that the } \\
\text { connections watched are like show- } \\
\text { stoppers. A comprehensive methodology } \\
\text { is expected to comprehend the suggestions } \\
\text { for research and kids' collaborations } \\
\text { during media story sharing. }\end{array}$ \\
\hline 8 & $\begin{array}{l}\text { (Widyatri et } \\
\text { al., 2018) }\end{array}$ & $\begin{array}{l}\text { Parental } \\
\text { control } \\
\text { application } \\
\text { on the } \\
\text { Android } \\
\text { platform }\end{array}$ & $\begin{array}{l}\text { Emerald } \\
\text { Publishing } \\
\text { Limited }\end{array}$ & \begin{tabular}{l|} 
Presentation of \\
encouraging \\
applications for \\
guardians to \\
control \\
different \\
applications \\
that might be \\
\end{tabular} & $\begin{array}{l}\text { Parental } \\
\text { control } \\
\text { application } \\
\text { survey }\end{array}$ & $\begin{array}{l}\text { This investigation's parental control } \\
\text { application was made utilizing java } \\
\text { dansqlite for cell phones just as php and } \\
\text { MySQL for workers. A portion of this } \\
\text { parental control application highlights the } \\
\text { application list, application history, GPS } \\
\text { following, time limit, concealed symbols, } \\
\text { and parental dashboard. }\end{array}$ \\
\hline
\end{tabular}




\begin{tabular}{|c|c|c|c|c|c|c|}
\hline & & & & $\begin{array}{l}\text { utilized by } \\
\text { youngsters. }\end{array}$ & & \\
\hline & $\begin{array}{l}\text { (Peck et al., } \\
2014)\end{array}$ & $\begin{array}{l}\text { Smartphone } \\
\text { Preventive } \\
\text { Health } \\
\text { Care: } \\
\text { Parental } \\
\text { Use of an } \\
\text { Immunizati } \\
\text { on } \\
\text { Reminder } \\
\text { System }\end{array}$ & $\begin{array}{l}\text { Journal of } \\
\text { Pediatric } \\
\text { Health } \\
\text { Care }\end{array}$ & $\begin{array}{l}\text { This } \\
\text { investigation } \\
\text { looks at the } \\
\text { practicality of } \\
\text { utilizing a cell } \\
\text { phone } \\
\text { application } \\
\text { update } \\
\text { framework for } \\
\text { inoculations } \\
\text { given in } \\
\text { essential } \\
\text { consideration } \\
\text { for youngsters. }\end{array}$ & $\begin{array}{l}\text { descriptive } \\
\text { study design }\end{array}$ & $\begin{array}{l}\text { Tests from guardians and parental figures } \\
\text { Members utilized an Android cell phone } \\
\text { Application that fills in as an } \\
\text { update/recollects framework for } \\
\text { immunizations and a device to get } \\
\text { dependable data about antibodies. There } \\
\text { is not completely assessed the handiness } \\
\text { of the cell phone application "Give } \\
\text { orders". Nonetheless, starter results and } \\
\text { criticism are positive, and the application } \\
\text { ought to be dispatched on an android } \\
\text { stage that contacts a more extensive } \\
\text { crowd of tests and Pediatric Medical care. }\end{array}$ \\
\hline & $\begin{array}{l}\text { (Nansen \& } \\
\text { Jayemanne, } \\
\text { 2016) }\end{array}$ & $\begin{array}{l}\text { Infants, } \\
\text { Interfaces, } \\
\text { and } \\
\text { Intermediati } \\
\text { on: Digital } \\
\text { Parenting } \\
\text { and the } \\
\text { Production } \\
\text { of "iPad } \\
\text { Baby" } \\
\text { Videos on } \\
\text { YouTube }\end{array}$ & $\begin{array}{l}\text { Journal of } \\
\text { Broadcasti } \\
\text { ng \& } \\
\text { Electronic } \\
\text { Media }\end{array}$ & $\begin{array}{l}\text { Investigate } \\
\text { how guardians } \\
\text { go about as } \\
\text { mediators } \\
\text { among } \\
\text { homegrown } \\
\text { and public } \\
\text { spaces } \\
\text { networks by } \\
\text { proposing the } \\
\text { idea of } \\
\text { intermediation, } \\
\text { which expands } \\
\text { on bits of } \\
\text { knowledge } \\
\text { from different } \\
\text { basic } \\
\text { examinations } \\
\text { just as social } \\
\text { industry } \\
\text { writing to help } \\
\text { represent the } \\
\text { created parts of } \\
\text { advanced } \\
\text { child-rearing. }\end{array}$ & $\begin{array}{l}\text { Analysis } \\
\text { Investigasi }\end{array}$ & $\begin{array}{l}\text { Guardians do not effortlessly direct the } \\
\text { utilization of media for kids at home. } \\
\text { However, go about as go-betweens in } \\
\text { adding to youngsters' online portrayal and } \\
\text { talk in advanced culture. This mediator } \\
\text { function of guardians includes } \\
\text { philosophical strain in finding the } \\
\text { importance of "effortlessness:" the iPad's } \\
\text { gestural presentation of advanced } \\
\text { spryness for youngsters. }\end{array}$ \\
\hline
\end{tabular}


21 Jurnal Ilmu dan Teknologi Kesehatan, Vol. 8, Nomor 1, September 2020, hlm:14-27

In a different writing, surveys acquired, as a rule, utilize android is valuable to help guardians who cannot ideally complete childcare. However, for this situation, the utilization of android is heavily influenced by guardians or well-being laborers who care for parental figures.

Research conducted by Altun (2019) it is discovered that the family has a TV, PC, PC, cell phone, and tablet offices. Kids access computerized data through PCs, tablets, cell phones, and guardians. Likewise, to be specific, they share data about youngsters via web-based media utilizing these offices, even though it is risky for the kid's personality security. Also, there are guardians' interests in this advanced media. It can cause enthusiastic improvement problems and reliance since they invest a great deal of energy utilizing computerized media.

What is more, there are a few guardians who uphold the utilization of advanced media. In an examination with an all-out example of 628 preschool youngsters and their folks, it was discovered that $97.5 \%$ of families have a TV at home, $43.45 \%$ have a work station,
$49 \%$ have a PC, have wireless, and $68 \%$ have a tablet. Of the youngsters who took an interest in the investigation, $86 \%$ utilized data and correspondence innovation, for example, PCs, tablets, or cell phones. Among guardians, $68 \%$ offer photographs of their kids on advanced stages.

Research by Kucirkova et al. (2013) discovered that the setting of sharing stories intervened by the guardians of the application to deliver an agreeable and smooth connection, accomplishing a lucidness that is commonplace of a great story. It shows that the connections watched take after masterpieces. An all-encompassing methodology is expected to comprehend the suggestions for examining and kids' cooperation during media story sharing. Instances of photograph display that guardians can make to animate youngsters and guardians' closeness when guardians or parents are not at home. 


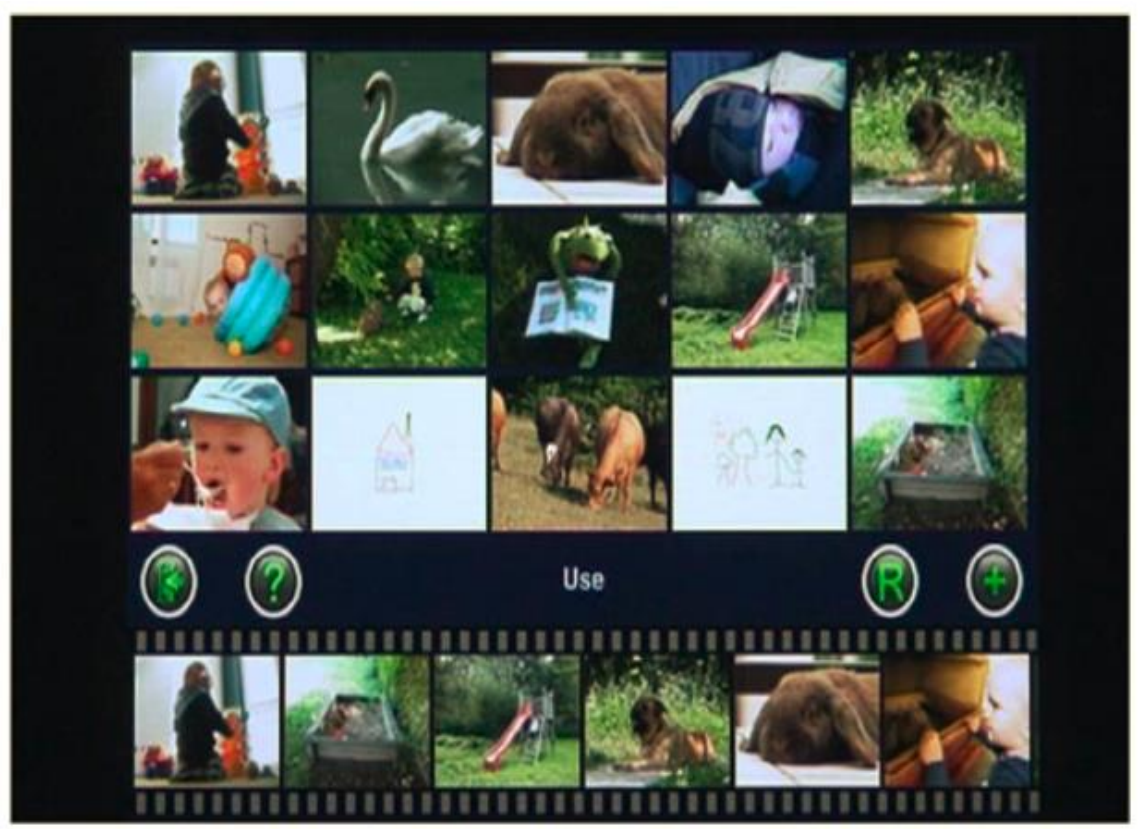

Figure 1. An example of a photo gallery

This was also stated by Wang et al. (2018), which examines that through the Android program, records, and assessments of youngster development and advancement are acquired, physical improvement is assessed depending on the sex of the kid, date of birth, weight, and tallness information. There is a development and improvement bend that can be attracted naturally as per the past development and advancement records of youngsters and dynamic following of kids' advancement the board to be accomplished. In this application, there are additionally different diagrams to gauge the healthful status of kids.
For small kids, a video association can significantly impact a similar impact as a physical presence. This is a huge discovering because it is the principal experimental exhibit and shows significant guarantee in video correspondence as a method for keeping up family connections when physical presence does not permit (Madianou \& Miller, 2011). It must be in adult monitoring. This is also illustrated by research (van Heerden et al., 2017), which is done with the assistance of the general well-being workforce who direct home visits by giving data to guardians. The portrayal of utilizing phones to follow youngsters' turn of events expands the certainty of parental figures in 
childcare, albeit at first, there are as yet numerous worries about how to utilize the phone cell.

This exploration has indicated that versatile data and correspondence innovation (ICT) can improve staff execution in their capacity to do well-being advancement, gather and report opportune data on family well-being, give well-being administrations, for example, antibodies, and allude families to proper nearby well-being administrations. . Furthermore, when portable ICT apparatuses are utilized by staff, the gadget can expand parental figure trust in the messages sent and increment staff trust in their work. Through the execution of science development, advancements in ICT and techniques for youngster well-being and improvement can be reached out to low-asset settings to engage assets and spread the advantages of propelling innovation (Westgard et al., 2019).

Research by Widyatri et al. (2018) to evade Android's negative impact on child-rearing techniques, the parental control application is made utilizing Java and SQLite for cell phones just as PHP and MySQL for workers. A portion of this parental control application highlights the application list, application history, GPS following, time limit, shrouded symbols, and parental dashboard.
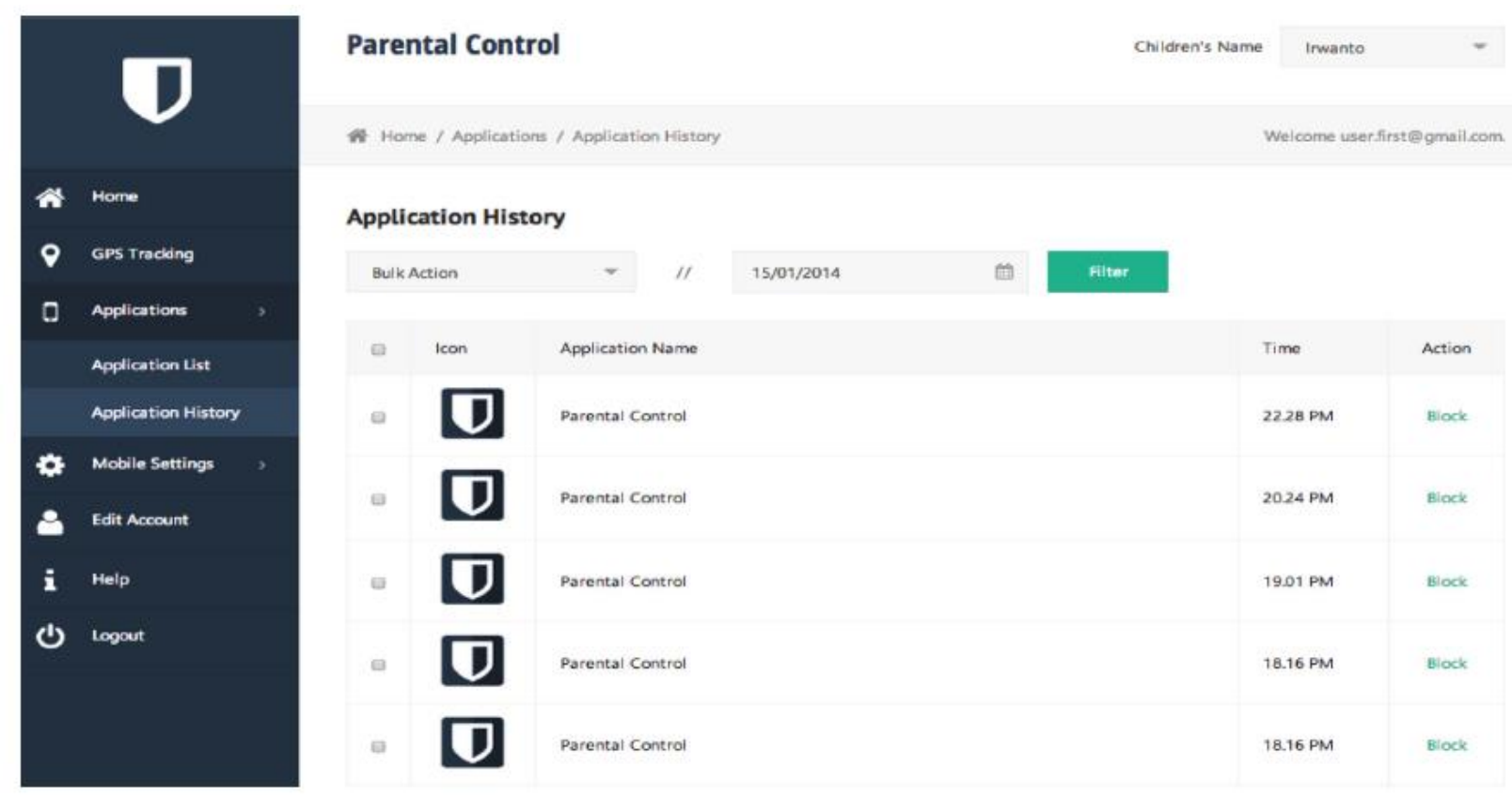

Figure 2. An example of a Parental Control application display 
In advanced child-rearing, guardians can likewise address kids' issues regarding medical services. That is, guardians and parental figures utilizing a cell phone application can get updates about frameworks for immunization and apparatuses to get solid data about antibodies. There is not completely assessed the helpfulness of the cell phone application 'Give orders'. Anyway, fundamental outcomes have a positive input, and the application ought to be dispatched on an android stage that can contact a more extensive crowd in pediatric medical care (Peck et al., 2014).

A few guardians, well-being laborers, or parental figures may at first think that it is troublesome in advanced child-rearing since it is difficult to direct media utilization for youngsters at home. However, it goes about as a middle person adding to kids' online portrayal and talk in the social period computerized. This middle person function of guardians includes philosophical pressure in finding the significance of "effortlessness" the iPad's gestural showcase of computerized deftness for youngsters (Nansen \& Jayemanne, 2016). As stated Papadakis \& Kalogiannakis (2017), there are many applications for picking the most proper instructive apparatuses for kids, and that will make the instructive cycle simpler for instructors and teachers the same.

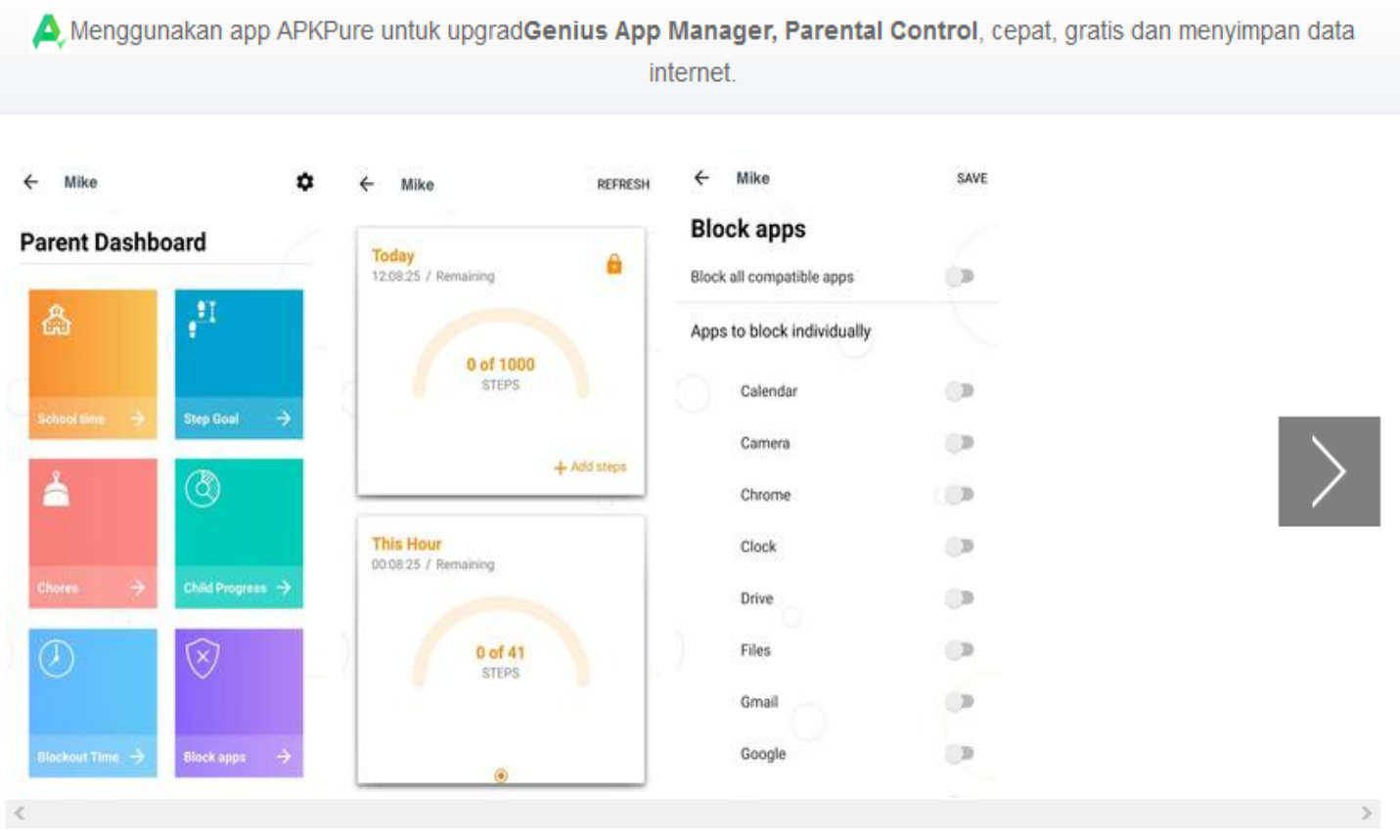

Figure 3. An example of a display of parental control applications in children's education 


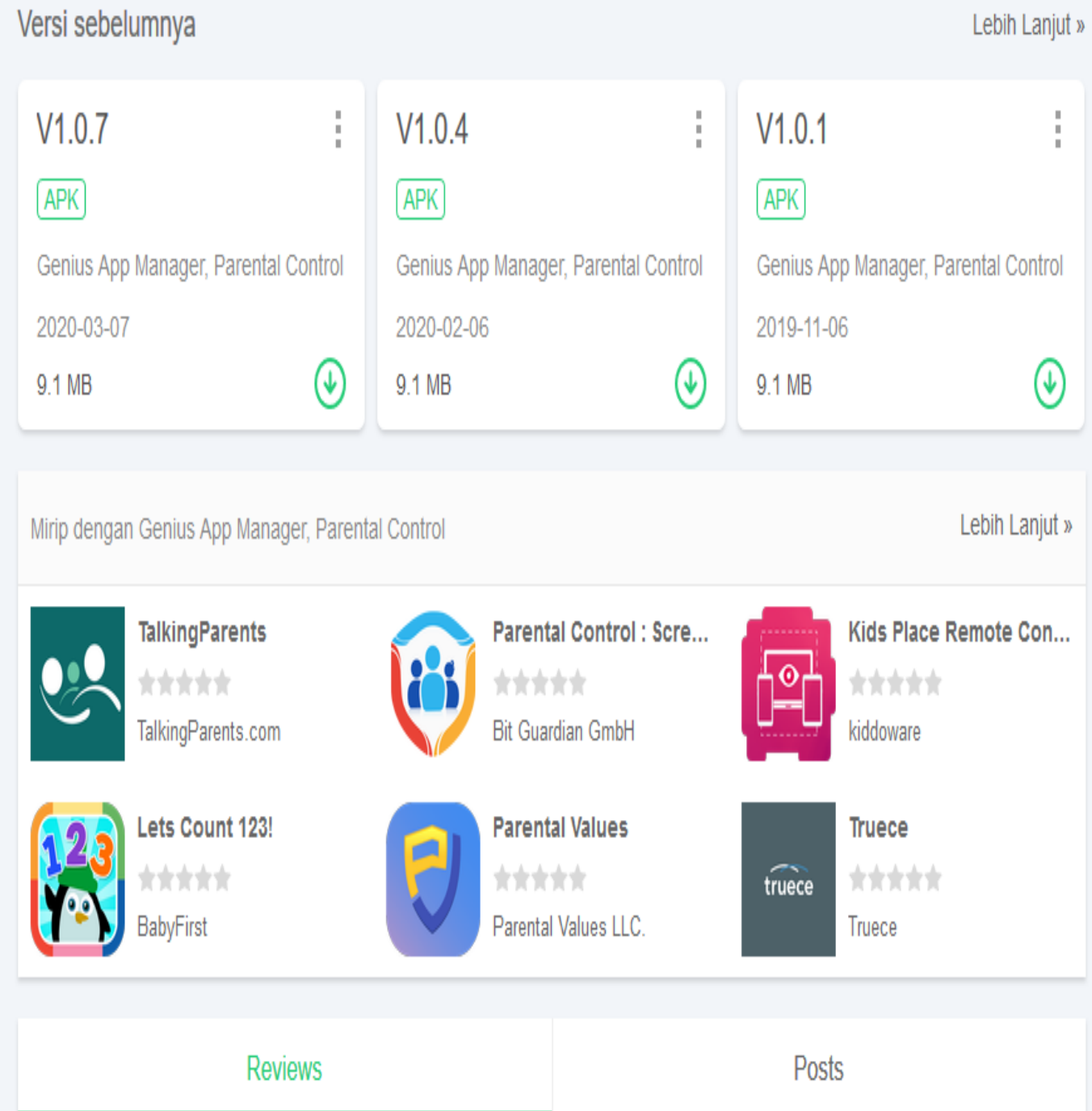

Figure 4. Example of digital parenting application

\section{CONCLUSION}

The advancement of kid-being nursing the board data framework can incorporate solid kids, wiped out kids, instruction, condition, and child-rearing that should be possible. Including 1) Entering the phases of kids' development and improvement in the application, 2) in the application can be included kinds of remuneration apparatuses and punishment of everyday exercises. The ramifications of building up youngster wellbeing nursing the executive's data framework during child-rearing are helpful as a preventive and promotive activity in kids' well-being. Youngster medical attendants can effectively and precisely distinguish issues that emerge in the preventive cycle, so they are relied upon to make nursing 
intercessions that are likewise spot on.

\section{REFERENCE}

Altun, D. 2019. An Investigation of Preschool Children's Digital Footprints and Screen Time. International Journal of Eurasia Social Sciences, 10(35): 7697.

Findahl, O. 2013. Svenskarna och Internet 2011.

Hardersen, B., \& Guðmundsdóttir, G. 2012. The digital universe of young children. Nordic Journal of Digital Literacy, 7(3):221-226.

KBBI, T. P. K. P. B. 2008. Kamus Bahasa Indonesia. Journal of Visual Languages \& Computing 11(3). Pusat Bahasa Departemen Pendidikan Nasional.

Kucirkova, N., Messer, D., Sheehy, K., \& Flewitt, R. 2013. Sharing personalized stories on iPads: A close look at one parent-child interaction. Literacy, 47(3): 115-122. https://doi.org/10.1111/lit.12003

Madianou, M., \& Miller, D. 2011. Mobile phone parenting: Reconfiguring relationships between Filipina migrant mothers and their left-behind children. New Media and Society, 13(3): 457470.

https://doi.org/10.1177/146144481039 3903

Nansen, B., \& Jayemanne, D. 2016. Infants, Interfaces, and Intermediation: Digital Parenting and the Production of "iPad Baby" Videos on YouTube. Journal of Broadcasting and Electronic Media, 60(4): 587-603. https://doi.org/10.1080/08838151.2016
.1234475

Papadakis, S., \& Kalogiannakis, M. 2017. Mobile educational applications for children. What educators and parents need to know. International Journal of Mobile Learning and Organisation, 11(2):

\section{1.} https://doi.org/10.1504/ijmlo.2017.100 03925

Peck, J. L., Stanton, M., \& Reynolds, G. E. S. 2014. Smartphone preventive health care: Parental use of an immunization reminder system. Journal of Pediatric Health Care, 28(1): 35-42. https://doi.org/10.1016/j.pedhc.2012.0 9.005

Soetjiningsih, \& IG. N. Gde Ranuh. 2016. Tumbuh Kembang Anak (Edisi 2). Jakarta: EGC.

Sudarmilah, E., \& Pratisti, W. D. 2014. Sistem Informasi dan Monitoring Tumbuh Kembang Balita Berbasis Web. Publikasi Ilmiah Universitas Muhammadiyah Surakarta. http://hdl.handle.net/11617/5627

Terri, K., \& Carman, S. 2012. Buku Ajar Keperawatan Pediatri (D. Widiarti, W. Praptiani, N. B. Subekti, \& E. A. Mardella (eds.); 2nd ed.). Jakarta: EGC.

Van Heerden, A., Sen, D., Desmond, C., Louw, J., \& Richter, L. 2017. AppSupported Promotion of Child Growth and Development by Community Health Workers in Kenya: Feasibility and Acceptability Study. JMIR MHealth and UHealth, 5(12):e182. https://doi.org/10.2196/mhealth.6911

Wang, L., Shi, C., \& Zhao, Z. 2018. The research and development of growth 
curve for children's height and weight on Android platform. Proceedings 2017 10th International Congress on Image and Signal Processing, BioMedical Engineering and Informatics, CISP-BMEI 2017, 2018January, $1-5$. https://doi.org/10.1109/CISPBMEI.2017.8302293

Westgard, C. M., Rivadeneyra, N., \& Mechael, P. 2019. MHealth tool to improve community health agent performance for child development: Study protocol for a cluster-randomized controlled trial in Peru. BMJ Open, 9(11): $\quad 1-11$. https://doi.org/10.1136/bmjopen-2018028361

Widyatri, I., Salman, A. G., \& Kanigoro, B. 2018. Parental control application on Android platform. Library $\mathrm{Hi}$ Tech News, $\quad 35(1)$ : $\quad 18-24$. https://doi.org/10.1108/LHTN-082017-0057 